\title{
Acellular dermal matrix used after large surgical ressection in ameloblastoma with buccal mucosa extension: a case report
}

Matriz dérmica acelular usadla após grande ressecção cirúrrgica em ameloblastoma com extensão da mucosa bucal: relato de caso

Matriz dérmica acelular utilizada después de una gran resección quirúrgica en ameloblastoma con extensión de mucosa bucal: reporte de un caso

Recebido: 11/10/2021 | Revisado: 16/10/2021 | Aceito: 20/10/2021 | Publicado: 21/10/2021

\author{
Humberto Jácome-Santos \\ ORCID: https://orcid.org/0000-0003-1105-2191 \\ Federal University of Pará, Brazil \\ E-mail: humbertoufpa@yahoo.com.br \\ Fernanda Luiza Araújo de Lima Castro \\ ORCID: https://orcid.org/0000-0001-9381-385X \\ Metropolitan Hospital Odilon Behrens, Brazil \\ E-mail: fernandaluiza.alc@gmail.com \\ Renata de Carcalho Lacerda \\ ORCID: https://orcid.org/0000-0002-9258-3260 \\ Faculty of Medical Sciences of Minas Gerais, Brazil \\ E-mail: renataclac@hotmail.com \\ Renata Gonçalves de Resende \\ ORCID: https://orcid.org/0000-0001-7610-0399 \\ Metropolitan Hospital Odilon Behrens, Brazil \\ E-mail: renatagresende@yahoo.com.br \\ Aline Fernanda Cruz \\ ORCID: https://orcid.org/0000-0002-4315-5366 \\ Federal University of Minas Gerais, Brazil \\ E-mail: alinecruzz16@gmail.com \\ Júlio César Tanos de Lacerda \\ ORCID: https://orcid.org/0000-0002-5570-3550 \\ Metropolitan Hospital Odilon Behrens, Brasil \\ E-mail: jctlacerda@uol.com.br
}

\begin{abstract}
Neoplastic, traumatic, and inflammatory diseases of the oral cavity and oropharynx frequently result in significant defects after resection, also, they may present challenge reconstruction. Regional and distant flaps such as skin grafts (SGs) are routinely used to cover mucosal defects arising from large resections, to restore tissue volume and preserve function. However, there are some disadvantages, mainly related to the donor site morbidity, including pain, risk of infection, occasional hypertrophic scar, and additional contracture resulting from a relative lack of dermis. Therefore, acellular dermal membrane (ADM) seems to be an applicable option to avoid those issues, and it has been shown good results for covering tissue defects. Thus, this study reports the first experience of using the double-layer dermal substitute (DLDS) (Nevelia ${ }^{\circledR}$ made by Symatese, France) in oral cavity, to cover and repair a buccal defect, immediately after a large resection of ameloblastoma extending to buccal mucosa. After surgical intervention and actually in follow-up, the patient shows good aesthetic and functional status, 24 months postoperatively. Thus, this DLDS seems to be a good resource in primary buccal reconstruction after extensive tumor resection. However, more studies are needed to be performed.
\end{abstract}

Keywords: Ameloblastoma; Acellular dermal membrane; Buccal reconstruction.

\section{Resumo}

Doenças neoplásicas, traumáticas e inflamatórias da cavidade oral e orofaringe frequentemente resultam em defeitos importantes após a ressecção, podendo também apresentar desafios para a reconstrução. Retalhos regionais e distantes, como enxertos de pele, são rotineiramente usados para cobrir defeitos de mucosa decorrentes de grandes ressecções, para restaurar o volume do tecido e preservar a função. No entanto, existem algumas desvantagens, principalmente relacionadas à morbidade da área doadora, incluindo dor, risco de infecção, cicatriz hipertrófica ocasional e contratura adicional resultante de uma relativa falta de derme. Portanto, a matriz dérmica acelular (MDA) parece ser uma opção aplicável para evitar esses problemas, e tem mostrado bons resultados na cobertura de defeitos 
teciduais. Assim, este estudo relata a primeira experiência do uso do substituto dérmico de dupla camada (SDDC) (Nevelia fabricado por Symatese, França) na cavidade oral, para cobertura e reparo de defeito bucal, imediatamente após grande ressecção de ameloblastoma com extensão para a mucosa bucal. Após a intervenção cirúrgica e atualmente em acompanhamento, o paciente apresenta bom estado estético e funcional, com 10 meses de pósoperatório. Assim, o SDDC parece ser um bom recurso na reconstrução bucal primária após extensa ressecção do tumor. Contudo, mais estudos precisam ser realizados.

Palavras-chave: Amelobrastoma; Matriz dérmica acelular; Reconstrução bucal.

\section{Resumen}

Las enfermedades neoplásicas, traumáticas e inflamatorias de la cavidad oral y la orofaringe a menudo dan como resultado defectos importantes después de la resección y también pueden presentar desafíos para la reconstrucción. Los colgajos regionales y distantes, como los injertos de piel, se utilizan de forma rutinaria para cubrir los defectos de la mucosa de resecciones grandes, para restaurar el volumen del tejido y preservar la función. Sin embargo, existen algunas desventajas, principalmente relacionadas con la morbilidad del área donante, que incluyen dolor, riesgo de infección, cicatrices hipertróficas ocasionales y contractura adicional resultante de una falta relativa de dermis. Por tanto, la matriz dérmica acelular (MDA) parece ser una opción aplicable para evitar estos problemas, y ha mostrado buenos resultados en la cobertura de defectos tisulares. Así, este estudio reporta la primera experiencia de uso de sustituto dérmico de doble capa (SDDC) (Nevelia fabricado por Symatese, Francia) en la cavidad oral, para la cobertura y reparación del defecto oral, inmediatamente después de una resección mayor de ameloblastoma con extensión a la cavidad bucal. mucosa oral. Tras la intervención quirúrgica y actualmente en seguimiento, el paciente se encuentra en buen estado estético y funcional a los 10 meses de la intervención. Por lo tanto, SDDC parece ser un buen recurso en la reconstrucción oral primaria después de una resección extensa del tumor. Sin embargo, es necesario realizar más estudios.

Palabras clave: Ameloblastoma; Matriz dérmica acelular; Reconstrucción bucal.

\section{Introduction}

Dermal substitutes such as acellular dermal matrix (ADM) are currently used for the treatment of large skin loss in patients presenting critical general health conditions, including severe burns, and to promote the healing process in chronic wounds. ADM has been used in skin tissue reconstruction since 1995. Its utility has been proven in some clinical practice, such as burn management, and abdominal wall or breast reconstruction. Also, the use of ADM in oral mucosa reconstruction has been investigated, and the literature has suggested promising results, showing high success rates.

$\mathrm{ADM}$ is a soft connective tissue graft generated through a decellularization process that preserves the skin extracellular matrix, acting as a support surface for cells. This graft is composed by many types of proteins and protein fibers, such as collagen and elastic or reticular fibers. When ADM is implanted in a surgical spot, it works as a scaffold for the growing new cells, leading subsequent cells incorporation and revascularization throughout fibroblasts, myofibroblasts, and other connective tissue cells.

Some animal-derived acellular dermal matrix have a removable semi-permeable silicone layer on top acting as a temporary epidermis, which provides immediate protection against infection, dehydration, micro-organisms and toxins. The bottom side consists of a 3-dimensional collagen structure, which is positioned within the defect, then gradually gets incorporated in the wound bed, in a process supported by natural wound-healing mechanisms such as local cell infiltration (neutrophils, macrophages, fibroblasts, and keratinocytes), and neovascularization. The set of both layers can be named as acellular bi-layer substitute or double-layer dermal substitute (DLDS).

Similarly to the large accidental burn and dermal tissue loss caused on the skin, neoplastic diseases of the oral cavity and oropharynx when surgically treated frequently can result in significant tissue loss after resection, which may demand a challenging reconstruction. Regional and distant flaps as skin grafts (SGs) are routinely used to restore tissue volume and preserve function after surgical procedures. However, there are some disadvantages related to the donor site, such as morbidity, pain, infection risk, occasional hypertrophic scar and additional contracture resulting from a relative lack of dermis.

Some oral tumors may demand an invasive treatment, such as ameloblastoma, which is a locally invasive benign odontogenic tumor with high recurrence rate in the long term. Even when recognizing that this lesion is histologically benign, 
it behaves as a slow-growing invasive tumor. Usually it remains asymptomatic until it reaches a large enough size to provoke bone expansion and perforation of the adjacent soft tissue, at which point the patient may perceive the tumor existence. They usually appear between 30-40 years of age and most of the cases (>80\%) are characterized as a mandibular intraosseous neoformation, particularly occurring around the molars region or at mandible ascending ramus area.

The treatment is based on surgical intervention, which may require an extensive resection. Thus, the intention is to achieve a complete lesion excision with less morbidity and complete tumor removal. A number of different treatment strategies have been previously reported, including local techniques (curettage, enucleation or marsupialization) or radical treatments (marginal or en-bloc segmental resection with safety margins and reconstruction of bone defect).

In cases that the tumor has affected a large area and is involving soft tissue, the reconstitution post surgery seems to be quite challenging. Thus, this study reports the first experience using a DLDS (Nevelia ${ }^{\circledR}$ made by Symatese, France) in oral cavity, intending to cover a buccal tissue defect after extensive resection of an ameloblastoma involving superficial mandibular bone and extending to the jugal mucosa.

\section{Methodology}

This is a clinical case report similar to the methodology described by Askin, et al., 2015. A 63-years-old male patient was referred to the Stomatology and Maxillofacial Oral Surgery Department at the Hospital Metropolitano Odilon Behrens (HMOB) presenting lesion on the right buccal mucosa. The extra-oral examination did not show any facial asymmetry [Fig. 1]. Intraoral examination showed proliferative, asymptomatic, erythematous and presenting granular tumor appearance, located in the right jugal mucosa and lower back alveolar mucosa, measuring approximately $45 \mathrm{~mm}$ in its largest extension [Fig. 2]. The patient reported 4 months of evolution since he noticed the lesion. The panoramic radiography reveled bone rarefaction, well delimited within the edentulous and atrophic mandible, measuring about $20 \mathrm{~mm}$ in its largest extension, occupying the posterior region of the mandibular right branch, extending from the alveolar crest to the mandibular canal [Fig. 3]. The diagnostic hypotheses were squamous cell carcinoma, mesenchymal origin tumor or odontogenic tumor. An incisional biopsy was performed under local anesthesia, and the surgical specimen was then referred for anatomopathological examination. The final diagnosis was ameloblastoma.

Figure 1 - Extra-oral appearance does not show any facial asymmetry.

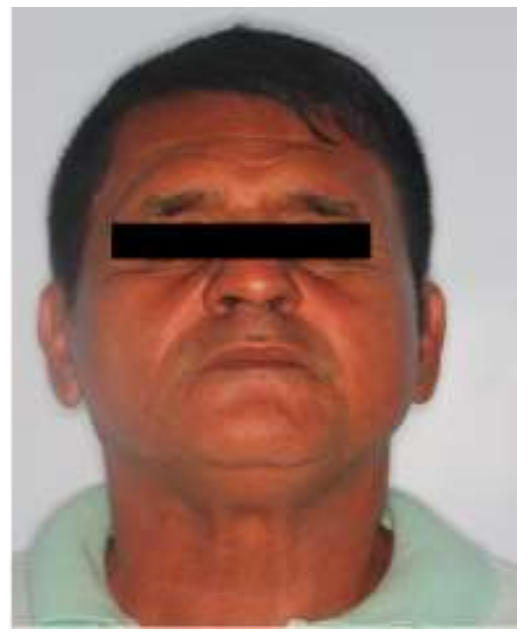

Source: Authors. 
Figure 2 - Intraoral examination showed proliferative, asymptomatic, erythematous and granular tumor appearance, located in the jugal mucosa and lower back alveolar mucosa, measuring approximately $45 \mathrm{~mm}$ in its largest extension.

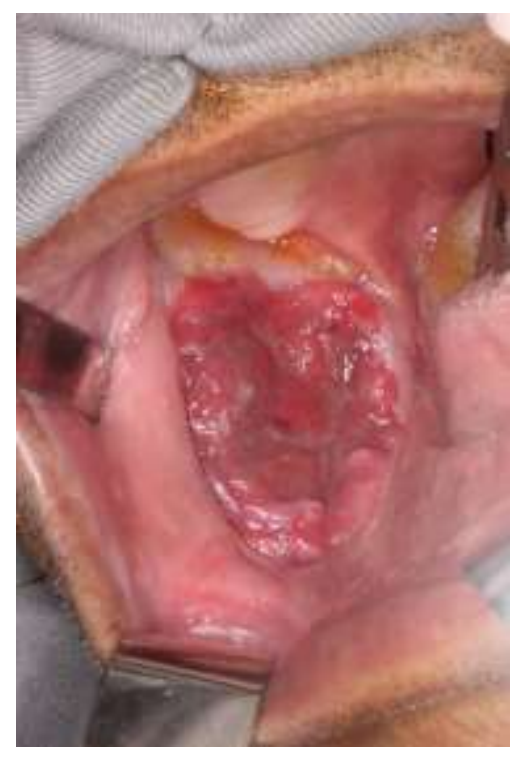

Source: Authors.

Figure 3 - The panoramic radiography reveled bone rarefaction measuring around $20 \mathrm{~mm}$ in its greatest extension, occupying the right posterior region of the mandible.

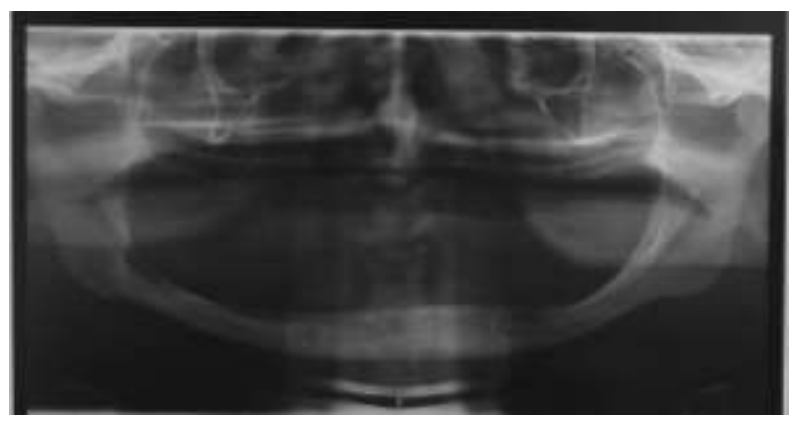

Source: Authors.

The patient was then submitted to tumor removal, under general anesthesia. The surgery was conducted by the bucomaxillofacial and plastic surgery clinics. In this case, it was utilized a DLDS (Nevelia® Bi-Layer Matrix - Symathese Biomateriaux, Chaponost, France), that consists of a $2 \mathrm{~mm}$ thick porous reabsorbable membrane made up of glutaraldehyde cross-linked bovine type I collagen with chondroitin-6-sulphate glycosamino- glycan (GAG), and a 2mm thick superior layer of polysiloxane polymer (silicone), mechanically reinforced with a polyester fabric. This bi-layer matrix is mainly used for dermal regeneration in individuals with skin loss, particularly in burns surgery, reconstructive plastic surgery, traumatology and resection of pathologies.

The surgical technique consisted of resection of the tumor mass infiltrated in the soft tissues (e.g. jugal and alveolar mucosa, part of the buccinator muscle and periosteum) and subsequent curettage and peripheral ostectomy at the affected mandibular bone portion with safety margin ranging around 5 to $10 \mathrm{~mm}$ in both bone and soft tissues [Fig. 4A-D and 6A]. Due to a large defect area resulting from the lesion excision, a buccal fat pad transposition was performed through the same incision to cover the exposed mandibular bone. Subsequently, the acellular dermal matrix was placed, covering all the surgical spot 
[Fig. 5 and 6B]. The internal surface of the collagen membrane was positioned facing the wound in order to guide epithelial regeneration and the external layer of polyester-reinforced silicone was facing the oral cavity, which worked as a pseudomucosa.

Figure 4 - A) Initial incision delimitation. B) The surgical technique was made by resection of the tumor mass infiltrated in the soft tissues, involving jugal and alveolar mucosa, part of the buccinator muscle and periosteum. C) Followed by curettage and peripheral ostectomy at the mandibular bone. D) Buccal fat pad transposition, for bone coverage.
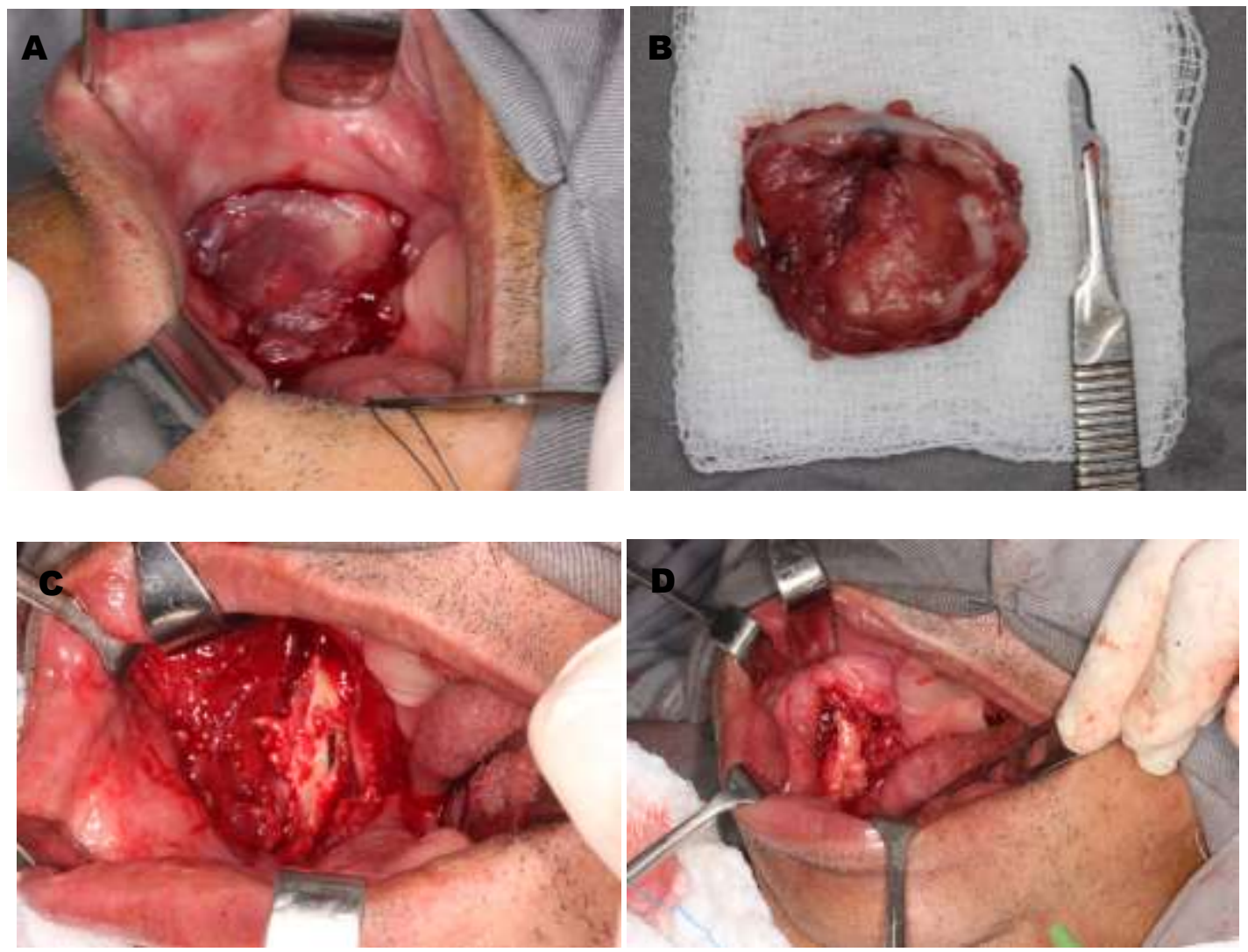

Source: Authors. 
Figure 5A and B - The dermal matrix used was a DLDS that measures $5 \times 5 \times 0.2 \mathrm{~cm}$. To adjust the DLDS at the surgical area, it was previously cut and placed easily within the surgical bed limits, being sutured at the edges of the remaining mucosa with absorbable 5-0 thread.
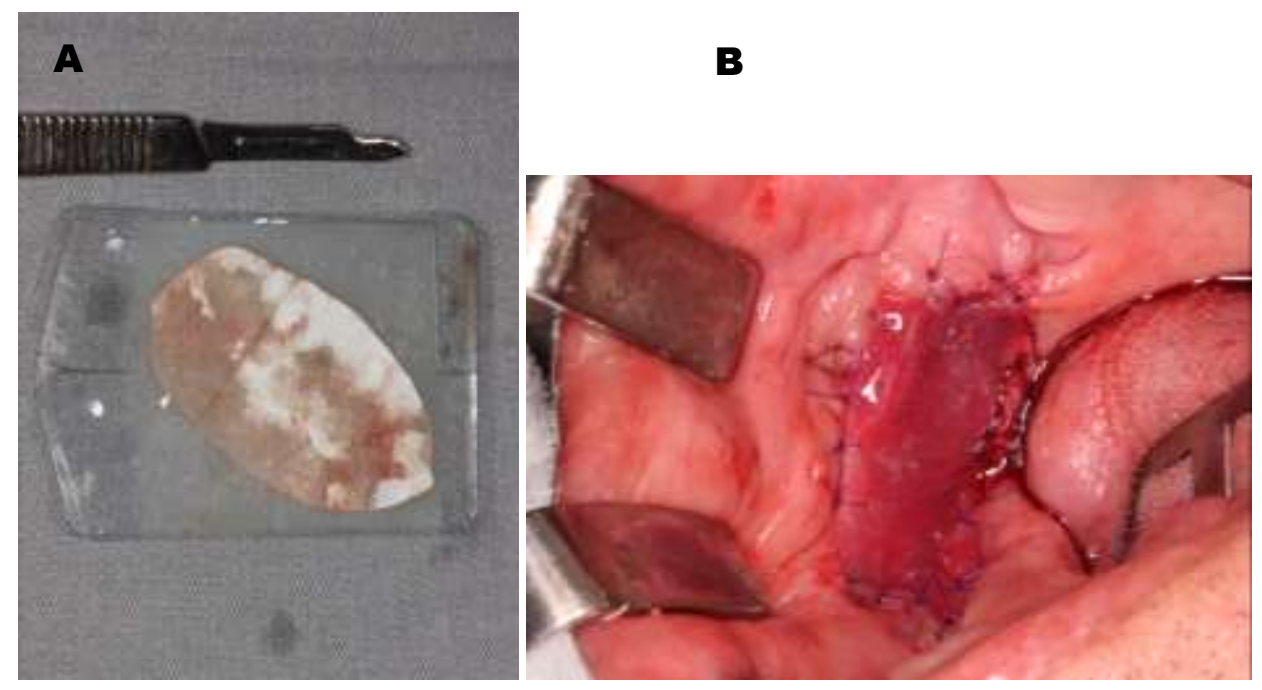

Source: Authors.

Figure 6 - A) It shows the resection area, and the surgical technique employed that was an incision on the margin of the lesion, in jugal and alveolar mucosa, which extended to the buccal floor, considering the necessity of a safety surgical margin (minimum of $5 \mathrm{~mm}$ ) to avoid recurrence. After delimitation and tumor removal in the soft tissues, the affected bone area was curetted and a peripheral osteotomy was performed. In addition, Carnoy solution was applied to the bone to decrease tumor recurrence risk. B) In view of the exposed bone area, a buccal fat pad transposition was performed to cover the exposed bone, followed by the composite matrix insertion. Resection area and cheek fat tissue donned were both covered by the DLDS, where the internal collagen layer was placed in contact with the surgical bed and the silicone layer was facing the buccal cavity. All procedures were made in a single surgical time.
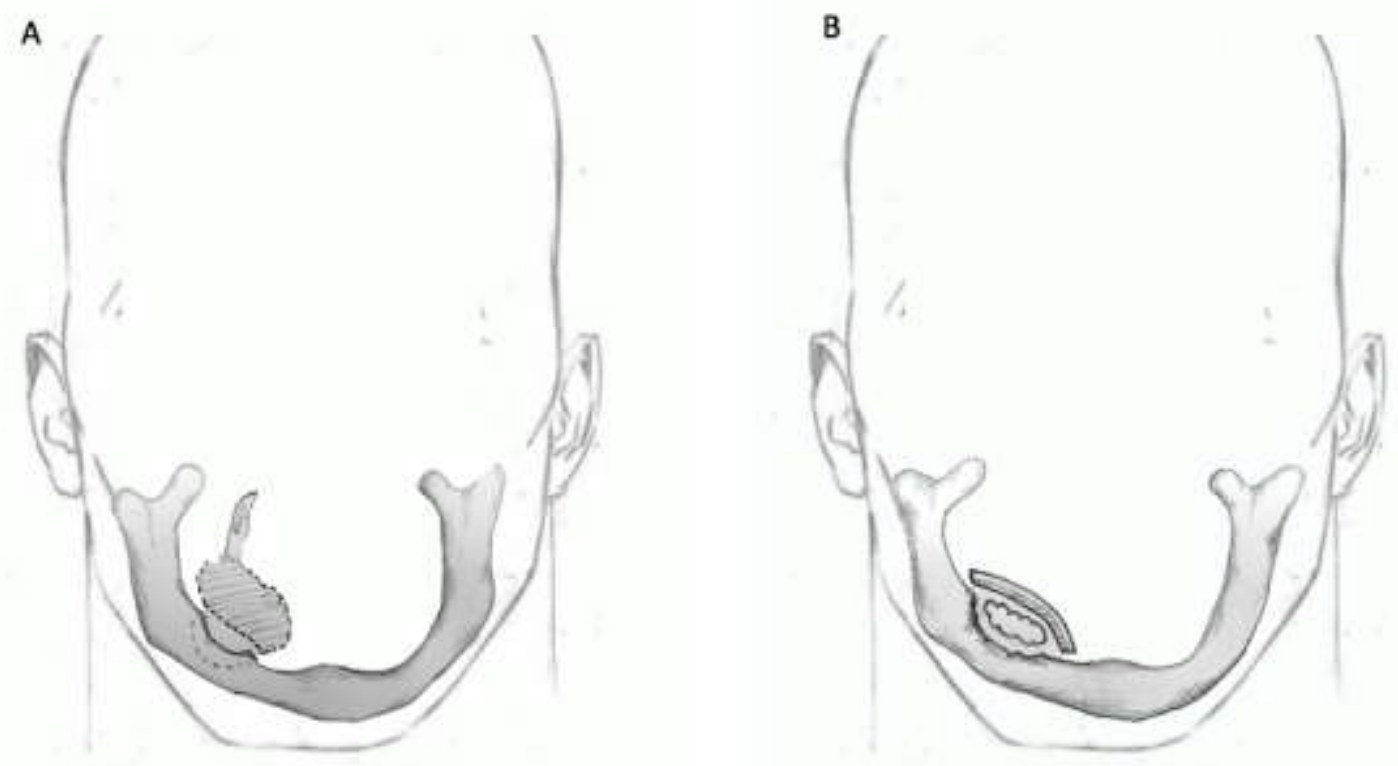

Source: Authors. 
The surgical specimen removed was then referred for anatomopathological examination and confirmed the previous diagnosis of ameloblastoma. The patient was discharged after 48 hours and had a good postoperative evolution. Bacterial infection and recurrent pain post surgery were absent. After 16 days, the dermal matrix was removed, and it was found out that the inner collagen layer was reabsorbed, while the outer silicone layer remained. A buccal epithelium neo-formatted was found under the matrix on the surgical spot, also having a similar appearance to the surround buccal mucosa. After 6 weeks postoperatively, the patient presented complete tissue repair, absence of mucosa scar or any tissue contractures. Then he kept in follow-up, and 24 months postoperatively, no evidence of tumor recurrence has been seen [Fig. 7A and B].

Figure 7 - A) The surgical area after 21 days. B) 60-day patient's follow-up.
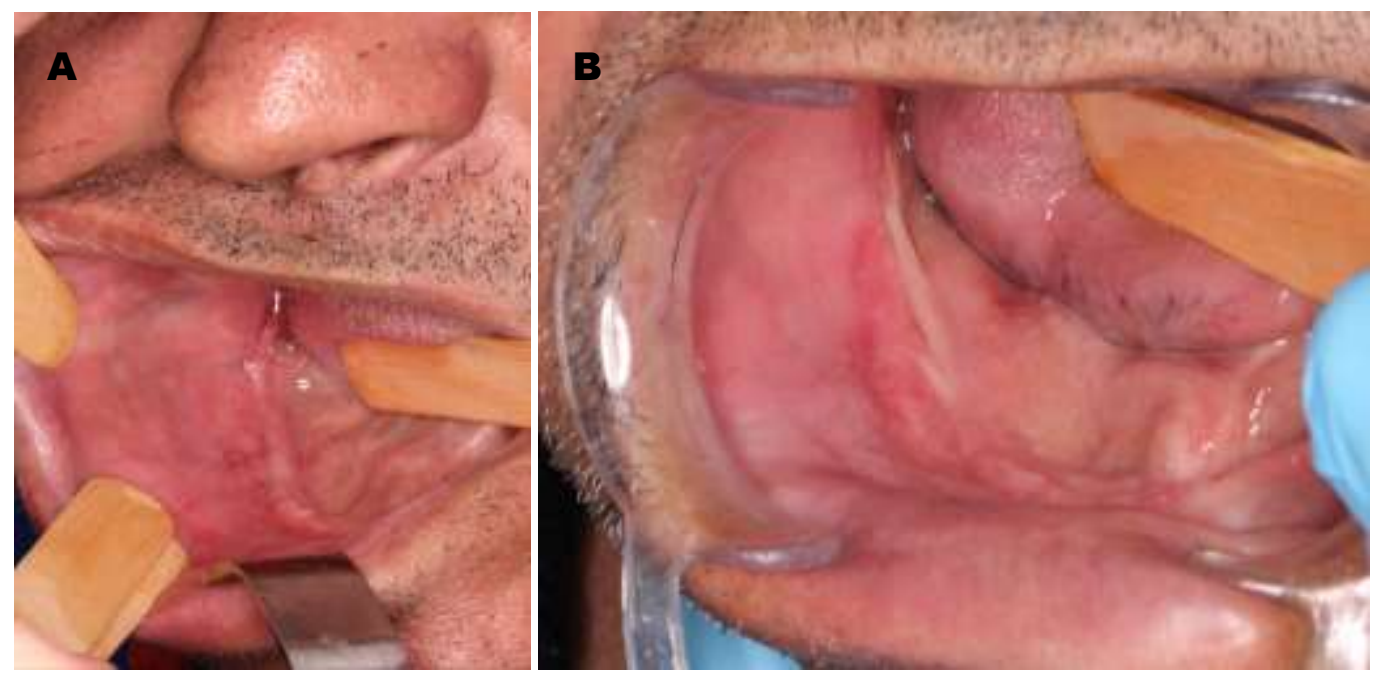

Source: Authors.

\section{Results and Discussion}

In recent years, there is a huge development in the field of tissue substitute engineering, intending to improve products designed to assist wound healing, such as ADM or DLDS. Dermal substitutes have many applications and can be a good resource for soft-tissue defects repair, due to ability to accelerate the healing process without rejection, and to reduce scar formation.

The convencional protocol for oral surgical tumor resection does not involve the use of an ADM. However, the good results obtained in other surgical procedures such as in cases of skin loss, burns, reconstructive plastic surgery, traumatology, and resection of pathologies, have also motivated the use of ADM as a substitute for mucosa in oral cavity.

In this case report, it was utilized a DLDS in association with a buccal fat pad transposition to reconstruct a buccal defect after large tumor resection of an ameloblastoma located at posterior mandible area and much of the jugal mucosa. No previous use of this DLDS in the human oral cavity has been reported in the English-language literature available.

The results were very satisfactory, and it seems to have a faster recovery than the conventional surgical technic, without a ADM. It could be explained by the fact that after implantation, ADM becomes quickly recolonized by fibroblasts and myofibroblasts, and other free cells of the connective tissue (lymphocytes, macrophages and multinucleated giant cells, granulocytes, mast cells), and also, relatively rapid ingrowth of blood vessels within the implanted ADM can be found, but lymphangiogenesis is a longer process than angiogenesis. The sequence of events are responsible to provide condition for rapid tissue repair ${ }^{3}$. Complementary, the study of Xu et al. (2018) which investigated in an animal model the underlying mechanisms 
by which ADM promotes wound healing in oral muccosa defects, and it was demonstrated that wounds treated with ADM exhibited a weak inflammatory reaction and faster epithelialization and revascularization, compared to untreated wounds.

Bacterial infection and recurrent pain post surgery were absent along the follow-up. It could be attributed to the fact that the collagen membrane creates physiological interface between wound and external environment working as a physical barrier (pseudo-epidermis) providing protection against mechanical trauma and reducing bacteria colonization on the wound surface, also. The ADM's smooth surface avoids food lodgment at the surgical site. In terms of pain reduction, this can be explained by the fact that the collagen membrane provides coverage for sensitive nerve endings, thereby diminishing degree of pain, specially after one week when regular dose and frequency of analgesic is withdrawn.

The case reported in this study showed an untypical ameloblastoma's behavior, that was growing mostly in muccosa than intraosseous, thus the tumor was located very superficial within the lower jaw bone. The large tumor size guided the choice to use the composite matrix to cover the surgical spot after tumor resection. Another possibility for covering it, would be the use of a free skin graft, which would require a donor area and some inconveniences could be seen, such as the possibility of hair follicles transposition, besides a different coloration from the buccal mucosa.

Some studies report the use of sking graft to help in covering large resections. However, when comparing the efficacy of ADM and split thickness skin grafts (STSG) in oral cavity defect reconstruction, ADM offers several advantages over STSG, including the lack of donor site morbidity, a natural appearing mucosal surface, and comparable or even superior functional status. In this sense, Rhee et al. (1998) published a study that examines the use of a commercially available ADM as an alternative to split thickness auto-grafting for avoiding the additional donor site morbidity. Twenty-nine patients with oral defects produced by tumor resection at the oral cavity in distinct locations were reconstructed with a processed allograft dermal matrix and the success rate was around $90 \%$ of all cases (26 of 29 patients exhibiting graft incorporation).

Furthermore, in a study using records from 36 patients that had oral mucosal defects reconstructed with ADM, the results were satisfactory and based on those data, the study suggests that ADM grafts are safe and efficient for clinical application in reconstruction of oral mucosal defects caused by various oral diseases.

The rapid growth of the new tissue is also an import to point. The study of De Angelis et al., (2018) reports the existence of a new tissue, histologically similar to the surround tissue, in 2 to 3 weeks posteriorly the implantation. In the present study, the patient was followed weekly for clinical evaluation of the surgical wound and the membrane's transparence facilitated visualizing the covered area, and the reinforced silicone flexibility avoided suture laceration. It could be seen satisfactory result with a complete oral epithelium proliferation at the healing area after 16 days within the range period showed in the study above, thus the ADM was removed.

\section{Final Considerations}

The technic applied seemed to work properly to the case, in which the patient patient had a large buccal mucosa resection and the DLDS could cover the lost soft tissue and stimulate the growth of the new one. The patient had satisfactory aesthetic and functional results quickly. Thus, the DLDS seems to be a good resource in primary buccal reconstruction after tumor resection. However, more studies shoud be performed for further conclusion.

\section{References}

Askin, S. B., Asku, A. E., Calis, M., Tulunoglu, I., Safak, T., Tozum, T. F. (2015). Report of multidisciplinary treatment of an extensive mandibular ameloblastoma with free iliac crest bone flap, dental implants, and acellular dermal matrix graft. J Oral Implantol, 41, $107-111$.

Basso, F. G., Hebling, J., Marcelo, C. L., de Souza Costa, C. A., Feinberg, S. E. (2016). Development of an oral mucosa equivalent using a porcine dermal matrix. Br J Oral Maxillofac Surg, 55, 308-311. 
Bohác, M., Danišovič, L., Koller, J., Dragúňová, J., Varga, I. (2018). What happens to an acellular dermal matrix after implanta- tion in the human body? A histological and electron microscopic study. European Journal of Histochemistry, 62, 2873.

Clark, R. A., Ghosh, K., Tonnesen, M. G. (2007). Tissue engineering for cutaneous wounds. J Invest Dermatol, 127, $1018-1029$.

Angelis, B., Orland, F., Morais Dáutilio, M. F. L., Scioli, M. G., Orlandi, A., Cervelli, V., Gentile, P. (2018). Long-term follow-up comparison of two different bi-layer dermal substitutes in tissue regeneration: Clinical outcomes and histological findings. Int Wound J, 15, 695-706.

Giord, D. A., Sykes, K., Jorgensen, J., Tawfik, O., Tsue, T. (2009). Acellular dermis compared to skin grafts in oral cavity reconstruction. Laryngoscope, 119, 2141-9.

Infante-Cossio, P., Prats-Golczer, V., Gonzalez-Perez, L. M., Belmonte-Caro, R., Martinez-De-Fuentes, R., Torres-Carranza, E., Gacto-Sanchez, P., GomezCia, T. (2013). Treatment of recurrent mandibular ameloblastoma. Experimental and Therapeutic Medicine, 6, $579-583$.

Menon, N. G., Rodriguez, E. D., Byrnes, C. K., Girotto, J. A., Goldberg, N. H., Silverman, R. P. (2003). Revascularization of human acellular dermis in fullthickness abdominal wall reconstruction in the rabbit model. Ann Plast Surg, 50, 523-7.

Milman, T., Ying, S., Pan, W., LiVolsi, V. (2016). Ameloblastoma: 25 Year Experience at a Single Institution. Head Neck Pathol, 10, 513-520.

Nicoletti, G., Tresoldi, M. M., Malovini, A., Visaggio, M., Faga, A., Scevola, S. (2018). Versatile use of dermal substitutes: A retrospective survey of 127 consecutive cases. Indian J Plast Surg, 51, 46-53.

Puisys, A., Vindasiute, E., Linkevciene, L., Linkevicius, T. (2014). The use of acellular dermal matrix membrane for vertical soft tissue augmentation during submerged implant placement: a case series. Clinical Oral Implants Research, 26, 465-470.

Reichart, P. A., Philipsen, H. P., Sonner, S. (1995). Ameloblastoma: biological profile of 3677 cases. Eur J Cancer Part B Oral Oncol, 31-D, 86-99.

Rhee, P. H., Friedman, C. D., Ridge, J. A., Kusiak, J. (1998) The use of processed allograft dermal matrix for intraoral resurfacing - An alternative to splitthickness grafts. Arch Otolaryngol Head Neck Surg, 124, 1201-1204.

Rijal, G. The decellularized extracellular matrix in regenerative medicine. (2017). Regen Med, 12, 475-7.

Schleifenbaum, S., Prietzel, T., Aust, G., Boldt, A., Fritsch, S., Keil, I., Koch, H., Möbius, R., Scheidt, H. A., Wagner M. F. X., Hammer, N. (2016). Acellularization-induced changes in tensile properties are organ specific - an in vitro mechanical and structural analysis of porcine soft tissues. PLoS One, 11.

Shi, L. J., Wang, Y., Yang, C., Jiang, W. W. (2012). Application of acellular dermal matrix in reconstruction of oral mucosal defects in 36 cases. J Oral Maxillofac Surg, 70, 586-91.

Singh, G., Mishra, M., Gaur, A., Srivastava, A., Shukla, B. (2018). Collagen Membrane Over Buccal Fat Pad Versus Buccal Fat Pad in Management of Oral Submucous Fibrosis: A Comparative Prospective Study. J. Maxillofac. Oral Surg 17, 484-487.

Wainwright, D. J. (1995) Use of an acellular allo- graft dermal matrix (AlloDerm) in the management of full-thickness burns. Burns, 21, 243-8.

Wright, J. M., Vered, M. (2017). Update from the 4th Edition of the World Health Organization Classification of Head and Neck Tumours. Neck Pathol, 11, $68-77$.

Xu, X., Cui, N., Wang, E. (2018). Application of an acellular dermal matrix to a rabbit model of oral mucosal defects. Experimental and therapeutic medicine, $15,2450-2456$. 